\title{
Quality and Composition of Virgin Olive Oil from Varietties Grown in Castilla-La Mancha (Spain)
}

\author{
Andres Alvarruiz* , Manuel Álvarez-Ortí, Braulia Mateos, Estela Sena and \\ Jose Emilio Pardo
}

Escuela Técnica Superior de Ingenieros Agrónomos (ETSIA), Campus Universitario, S/N, 02071 Albacete (Spain)

\begin{abstract}
The regulated physicochemical quality parameters (free acidity, peroxide value and UV absorption characteristics), sensory parameters (median of fruity, median of defect, panel classification, bitterness and pungency), stability parameters (total phenols and oxidative stability at $100^{\circ} \mathrm{C}$ ) and chemical composition (fatty acids, sterols and triterpenic dialcohols) of virgin olive oils obtained from 12 olive varieties cultivated in 6 of the most representative zones of Castilla-La Mancha (La Alcarria, Campos de Calatrava, Campos de Hellín, Campos de Montiel, Montes de Toledo and Sierra de Alcaraz) were evaluated. The varieties Cornicabra and Picual showed remarkable total polyphenols content and high stability, in contrast with Arbequina. The other less common varieties were in-between these two groups. Cornicabra and Picual showed also high oleic and low linoleic acids content, while Arbequina showed low oleic, high linoleic high palmitic and high palimitoleic acid content. The varieties Benizal and Cornicabra showed very high campesterol content. Benizal stood out by its high stigmasterol, low apparent $\beta$-sitosterol and low total sterols content, and the latter was below the established limit for olive oil. Triterpenic dialcohol content was significantly lower for Arbequina than for Cornicabra.
\end{abstract}

Key words: virgin olive oil, quality, sensory, variety, origin

\section{Introduction}

The olive trees (Olea europea) are cultivated mainly in the Mediterranean Basin. EU countries account for 70-80\% of the world production. Italy and Spain are the two main producing countries and together they represent about $75 \%$ of the total surface and production ${ }^{1)}$. Spain had in 2008 a surface of olive plantations of about $2.5 \cdot 10^{6}$ ha. Castilla-La Mancha had about $350 \cdot 10^{3}$ ha, being the second most important region after Andalusia. Most of the olive plantation surface in Castilla-La Mancha is concentrated in two Provinces: Ciudad Real and Toledo, which sum about $70 \%$ of the total surface.

Most of the olive plots in Castilla-La Mancha are located in marginal areas, subject to harsher climatic conditions than the Andalusian olive groves and yielding a much lower production. Thus, although the area planted in Castilla-La Mancha accounts for $14 \%$ of Spain's olive surface, its oil production accounts for only 6-7\% of national production. Therefore, characterization and differentiation of the oil produced in this region is vital to compete in an increasingly global market.

The most characteristic and common variety in Castilla-
La Mancha is Cornicabra. The Picual variety predominates in the South of the region on the border with Andalusia. Recently, intensive irrigated plantations of the variety Arbequina, whose oil is prized for its sensory properties, have been set up. The quality and characteristics of the variety Cornicabra in Castilla-La Mancha have been thoroughly studied ${ }^{2-5)}$. Papers have also been published on the quality of oil produced in certain areas of Castilla-La Mancha: Campo de Montiel ${ }^{6)}$, Montes de Alcaraz ${ }^{7)}$ and Campos de Hellin ${ }^{8)}$. However, a study that characterizes the olive oil produced in the region of Castilla-La Mancha, including the main varieties of olives grown in the region, has not been done.

Virgin olive oil is obtained by exclusively physical extraction methods (pressure, centrifugation or sedimentation). Traditionally, its characterization has been performed based on the regulated analytical parameters that are related to a possible state of deterioration, rather than positive intrinsic qualities. Regulated physicochemical parameters are required by law for the commercial classification of olive oils, but do not take into account the special properties of these oils and their advantages compared to other

\footnotetext{
*Correspondence to: Andres Alvarruiz, Escuela Técnica Superior de Ingenieros Agrónomos (ETSIA), Campus Universitario, S/N, 02071 Albacete (Spain)

E-mail: Andres.Alvarruiz@ uclm.es

Accepted July 5, 2015 (received for review May 6, 2015)

Journal of Oleo Science ISSN 1345-8957 print / ISSN 1347-3352 online

http://www.jstage.jst.go.jp/browse/jos/ http://mc.manusriptcentral.com/jjocs
} 
vegetable fats.

Oil stability determines the product shelf life and is related to its content in phenolic compounds, which are natural antioxidants present in olive oils and are shown to have beneficial properties on human health ${ }^{9,10)}$.

Fatty acid composition is highly dependent on genetic and environmental factors and has been previously used for classification of virgin olive oils ${ }^{11-15)}$.

The composition of the sterol fraction is a very useful parameter to detect adulteration, since it can be considered a real fingerprint of olive oil ${ }^{16)}$. It has been found that some varieties, such as Cornicabra sometimes exceed the upper limits set for campesterol in virgin olive oil ${ }^{2,3,5,17)}$. The percentage of triterpenic dialcohols (erythrodiol and uvaol) is also limited in virgin olive oil ${ }^{18)}$.

The objective of this work was to characterize the olive oils from Castilla-La Mancha region and determine the influence of the variety on the regulated quality parameters, stability and chemical composition.

\section{Material and methods}

\subsection{Selection of plots and trees within the studied zone}

A total of 128 plots were selected in 6 different zones, planted with 12 different varieties (Table 1). Within each plot, 6 typical trees of the represented variety were selected and marked. The genetic and morphological characterization and identification of the trees was done at the Cátedra de Pomología, Escuela Técnica Superior de Ingenieros Agrónomos y de Montes, Córdoba(Andalucía, España).

\subsection{Sampling}

Samples were taken at two precise moments: (i) the beginning of the harvest season (first fortnight of December 2010), when most of the fruits had purple-black skin and green flesh, although some of them still had green skin, and (ii) the middle-end of the harvest season (second fortnight of January 2011), when all the fruits were ripe, some of them even over-ripe. In both cases the sampling was began by the earlier varieties. The total number of samples was 256 ( 128 plots $\times 2$ collections $)$. The results of the first and second sampling were combined for the statistical analysis.

In each plot, $15 \mathrm{~kg}$ of healthy olives were picked by hand from the selected trees at the beginning and at the end of the harvest season and put into net bags. The samples were labelled and taken rapidly to a pilot plant for the extraction of olive oil at the Escuela Técnica Superior de Ingenieros Agrónomos (ETSIA), Albacete.

\subsection{Olive oil extraction}

An experimental oil mill comprising a hammer mill, ma-
Table 1 Number of sampled plots in each studied area for each variety.

\begin{tabular}{|c|c|c|}
\hline Zone & Variety & Sampled plots \\
\hline \multirow[t]{4}{*}{ Campo de Calatrava } & & 14 \\
\hline & Arbequina & 1 \\
\hline & Cornicabra & 8 \\
\hline & Picual & 5 \\
\hline \multirow[t]{6}{*}{ Campo de Montiel } & & 29 \\
\hline & Arbequina & 2 \\
\hline & Cornicabra & 10 \\
\hline & Manzanilla de Centro & 3 \\
\hline & Manzanilla Local & 2 \\
\hline & Picual & 12 \\
\hline \multirow[t]{10}{*}{ Campos de Hellín } & & 36 \\
\hline & Arbequina & 6 \\
\hline & Benizal & 4 \\
\hline & Cornicabra & 6 \\
\hline & Cuquillo & 4 \\
\hline & Injerta & 2 \\
\hline & Manzanilla de Sevilla & 2 \\
\hline & Manzanilla Local & 2 \\
\hline & Negrilla & 2 \\
\hline & Picual & 8 \\
\hline \multirow[t]{2}{*}{ La Alcarria } & & 12 \\
\hline & Castellana & 12 \\
\hline \multirow[t]{4}{*}{ Montes de Toledo } & & 16 \\
\hline & Arbequina & 1 \\
\hline & Cornicabra & 14 \\
\hline & Picual & 1 \\
\hline \multirow[t]{6}{*}{ Sierra de Alcaraz } & & 21 \\
\hline & Cornicabra & 6 \\
\hline & Manzanilla de Centro & 2 \\
\hline & Manzanilla Local & 2 \\
\hline & Onil & 2 \\
\hline & Picual & 9 \\
\hline
\end{tabular}

laxator and decanter (Oliomio TF-30, Toscana Enológica Mori, Tavarnelle Val di Pesa- Fl-Italia) was used. The oil mill worked in the 2-phase system. About $2 \mathrm{~L}$ of oil was obtained from each olive sample. The oil was decanted and placed in small bottles for further analysis.

\subsection{Analytical determinations}

Determination of the regulated physicochemical quality parameters (free acidity, peroxide value and UV absorption characteristic, $\mathrm{K}_{270}$ and $\mathrm{K}_{232}$ ), was carried out following the 
analytical methods described by Regulation EU 1348/2013 of the Commission of the European Union ${ }^{18)}$.

Free acidity, given as \% of oleic acid, was determined by titration of a solution of oil dissolved in ethanol/ether (1:1) with ethanolic potash.

Peroxide value, expressed in milliequivalents of active oxygen per kilogram of oil (meq/kg), was determined as follows: a mixture of oil and chloroform-acetic acid was left to react with a solution of potassium iodide in darkness; the free iodine was then titrated with a sodium thiosulfate solution.

$\mathrm{K}_{270}$ and $\mathrm{K}_{232}$ extinction coefficients were calculated from absorption at 270 and $232 \mathrm{~nm}$, respectively, with an UV spectrophotometer (Hewlett-Packard, HP 8452A), using a $1 \%$ solution of oil in cyclohexane and a path length of 1 $\mathrm{cm}$.

Sensory analysis (median of fruity, median of defects, panel classification, bitterness and pungency) of the samples was carried out by 12 selected and trained panellists from the panel of Laboratorio Agroalimentario de Granada (Atarfe, Granada, Spain), according to the method described by Regulation EU $1348 / 2013^{18)}$. The intensity of bitterness and pungency was evaluated as the percentage of samples with the attribute value higher than 5 on the 10 -cm scale shown in the profile sheet provided.

Total phenols compounds were determined by Folin-Ciocalteau colorimetric method. A solution of $10 \mathrm{~g}$ of oil in 75 $\mathrm{mL}$ of hexane was extracted with a water/methanol mixture (60:40), three times and completed to $100 \mathrm{~mL}$ with distilled deionized water. A $2 \mathrm{~mL}$ aliquot of the methanolic extract was mixed with $1 \mathrm{~mL}$ Folin-Ciocalteau reagent (Merck), $2 \mathrm{~mL}$ saturated sodium carbonate and $15 \mathrm{~mL}$ of distilled water and the absorptions of the solution at 725 $\mathrm{nm}$ were measured. Values were given as mg of caffeic acid per kg of oil ${ }^{19)}$.

Oxidative stability was evaluated by the Rancimat method $^{20)}$. Stability was expressed as the oxidation induction time(hours), measured with the Rancimat 679 apparatus (Metrohm Co., Basel, Switzerland), using an oil simple of $3.5 \mathrm{~g}$ warmed to $100^{\circ} \mathrm{C}$ and air flow of $10 \mathrm{~L} / \mathrm{h}$.

For the determination of fatty acid composition (\%), the methyl-esters were prepared by vigorous shaking of a solution of oil in hexane $(0.2 \mathrm{~g}$ in $3 \mathrm{~mL})$ with $0.4 \mathrm{~mL}$ of $2 \mathrm{~N}$ methanolic potash, and analysed by GC with a HewlettPackard (HP 6890) chromatograph equipped with a FID Detector. A fused silica column $(50 \mathrm{~m}$ length $\times 0.25 \mathrm{~mm}$ i. d.), coated with SGL-1000 phase (0.25 $\mu \mathrm{m}$ thickness; Sugerlabor), was used. Helium was employed as carrier gas with a flow through the column of $1 \mathrm{~mL} / \mathrm{min}$. The temperatures of the injector and detector were set at $250^{\circ} \mathrm{C}$ whereas the oven temperature was $210^{\circ} \mathrm{C}$. An injection volume of $1 \mu \mathrm{L}$ was used (Regulation EC 2568/91, corresponding to AOCS method Ch 2-91).

Sterols (\%) were determined by a Hewlett-Packard (HP
6890) gas chromatograph with a capillary column $(25 \mathrm{~m}$ length $\times 0.25 \mathrm{~mm}$ i.d.) coated with SGL-5 (0.25 $\mu \mathrm{m}$ thickness; Sugerlabor), as explained elsewhere ${ }^{21)}$. Working conditions were as follows: carrier gas, helium; flow through the column, $1.2 \mathrm{~mL} / \mathrm{min}$; injector temperature, $280^{\circ} \mathrm{C}$; detector temperature, $290^{\circ} \mathrm{C}$; oven temperature, $260^{\circ} \mathrm{C}$; injection volume $1 \mu \mathrm{L}$ (Regulation EC 2568/91, corresponding to AOCS method Ch 6-91). Apparent $\beta$-sitosterol included the sum of $\beta$-sitosterol, $\Delta 5,23$-stigmastadienol, clerosterol, sitostanol and $\Delta 5,24$-stigmastadienol.

Analytical determinations were carried out at least in duplicate.

\subsection{Statistical analysis}

Significant differences among varieties were determined by an analysis of variance applying a Tukey test with a $95 \%$ significant level $(p<0.05)$, using the SPSS programme for Windows.

\section{Results and discussion}

Table 2 shows the physicochemical and sensory quality parameters for the olive oil samples from different varieties grown in the studied area. All the produced and analysed oils showed very low values for the regulated physicalchemical parameters evaluated (acidity $\leq 0.8 \%$, peroxide index $\leq 20$ meq $\mathrm{O}_{2} / \mathrm{kg}, \mathrm{K}_{232} \leq 2.5, \mathrm{~K}_{270} \leq 0.22$ ), meaning high olive oil quality. This result was expected, because the olive samples were carefully picked, and the oil was extracted under optimal conditions. Therefore, all the oil samples were classified as "extra virgin" category, as stated by Regulation EU 1348/2013 ${ }^{18)}$. The variety Cuquillo gave the highest values of free acidity, significantly different from Arbequina, Benizal, Castellana and Negrilla. Cuquillo showed also the highest peroxide values, but only significantly different from Cornicabra, Onil and Picual. There were not significant differences in the ultraviolet absorbance parameters $\left(\mathrm{K}_{270}, \mathrm{~K}_{232}\right)$ between varieties.

Table 2 shows the sample average of the median of fruity for each variety. Fruity was always higher than 0 and there were not significant differences in this attribute. The median of defects was equal to zero (data not shown in Table 2), and therefore all the samples were classified as extra virgin oil ${ }^{18)}$.

The varieties Arbequina and Negrilla had similar characteristics as regards bitterness and pungency. All the samples of both varieties had values less than 5 for these positive attributes. Note that the phenols content and oxidative stability of Negrilla were lower but not significantly different than those of Manzanilla Local, while the bitterness and pungency of the former were strongly higher than the latter. The reason for this apparent inconsistency could be that the number of samples of these minor varieties was 
Table 2 Regulated physicochemical and sensory parameters for the different olive varieties.

\begin{tabular}{|c|c|c|c|c|c|c|c|}
\hline \multirow[b]{2}{*}{ Variety (n) } & \multicolumn{4}{|c|}{ Regulated physicochemical parameters ${ }^{(1)}$} & \multicolumn{3}{|c|}{ Sensory parameters } \\
\hline & $\begin{array}{c}\text { Free acidity } \\
\text { (g/100 g) }\end{array}$ & $\begin{array}{l}\text { Peroxide value } \\
\quad(\mathrm{meq} / \mathrm{kg})\end{array}$ & $K_{232}$ & $\mathbf{K}_{270}$ & $\begin{array}{c}\text { Fruity }^{(2)} \\
(0-10)\end{array}$ & $\begin{array}{c}\text { Bitterness }^{(3)} \\
(\%)\end{array}$ & $\begin{array}{c}\text { Pungency }^{(3)} \\
(\%)\end{array}$ \\
\hline Arbequina (10) & $0.13 \pm 0.05^{\mathrm{ab}}$ & $6.3 \pm 2.1^{\mathrm{ab}}$ & $1.688 \pm 0.158$ & $0.092 \pm 0.016$ & $4.96 \pm 0.56$ & 0 & 0 \\
\hline Benizal (4) & $0.13 \pm 0.05^{\mathrm{ab}}$ & $5.5 \pm 1.2^{\mathrm{ab}}$ & $1.658 \pm 0.096$ & $0.124 \pm 0.012$ & $5.40 \pm 0.57$ & 37,5 & 87,5 \\
\hline Castellana (12) & $0.10 \pm 0.00^{\mathrm{a}}$ & $6.0 \pm 0.8^{\mathrm{ab}}$ & $1.710 \pm 0.088$ & $0.105 \pm 0.006$ & $3.57 \pm 1.08$ & 25 & 75 \\
\hline Cornicabra (44) & $0.18 \pm 0.07^{\mathrm{abc}}$ & $4.4 \pm 1.9^{\mathrm{a}}$ & $1.578 \pm 0.164$ & $0.118 \pm 0.029$ & $6.21 \pm 4.48$ & 68,2 & 75 \\
\hline Cuquillo (4) & $0.23 \pm 0.05^{\mathrm{c}}$ & $7.7 \pm 2.2^{\mathrm{b}}$ & $1.657 \pm 0.139$ & $0.114 \pm 0.029$ & $5.46 \pm 0.75$ & 50 & 75 \\
\hline Injerta (2) & $0.13 \pm 0.05^{\mathrm{abc}}$ & $5.7 \pm 1.2^{\mathrm{ab}}$ & $1.606 \pm 0.053$ & $0.103 \pm 0.019$ & $5.61 \pm 1.16$ & 25 & 50 \\
\hline Manzanilla de Centro (5) & $0.15 \pm 0.05^{\mathrm{abc}}$ & $4.7 \pm 1.3^{\mathrm{ab}}$ & $1.607 \pm 0.114$ & $0.105 \pm 0.012$ & $6.16 \pm 0.57$ & 40 & 30 \\
\hline Manzanilla de Sevilla (2) & $0.21 \pm 0.11^{\mathrm{bc}}$ & $6.7 \pm 1.2^{\mathrm{ab}}$ & $1.616 \pm 0.138$ & $0.101 \pm 0.019$ & $5.77 \pm 0.46$ & 25 & 75 \\
\hline Manzanilla Local (6) & $0.16 \pm 0.05^{\mathrm{abc}}$ & $5.0 \pm 1.3^{\mathrm{ab}}$ & $1.689 \pm 0.107$ & $0.129 \pm 0.013$ & $5.16 \pm 1.26$ & 100 & 58,3 \\
\hline Negrilla (2) & $0.10 \pm 0.00^{\mathrm{a}}$ & $6.1 \pm 0.7^{\mathrm{ab}}$ & $1.753 \pm 0.049$ & $0.103 \pm 0.025$ & $5.40 \pm 0.53$ & 0 & 0 \\
\hline Onil (2) & $0.13 \pm 0.06^{\mathrm{abc}}$ & $4.2 \pm 3.0^{\mathrm{a}}$ & $1.563 \pm 0.127$ & $0.097 \pm 0.006$ & $4.50 \pm 1.32$ & 75 & 75 \\
\hline Picual (35) & $0.15 \pm 0.06^{\mathrm{abc}}$ & $4.3 \pm 2.0^{\mathrm{a}}$ & $1.552 \pm 0.133$ & $0.121 \pm 0.031$ & $5.31 \pm 1.07$ & 64,3 & 52,9 \\
\hline
\end{tabular}

n: number of samples; ${ }^{\mathrm{a}, \mathrm{b}, \mathrm{c}}$ : Different superscripts for the same quality parameter mean significant differences among varieties;

(1) Mean $\pm \mathrm{SD}$ (2): Mean of median of fruity $\pm \mathrm{SD}$; (3): percentage of samples with sensory parameters higher than 5.

Table 3 Stability parameters (mean \pm SD) for the different olive varieties.

\begin{tabular}{lcc}
\hline \multicolumn{1}{c}{ Variety (n) } & $\begin{array}{c}\text { Total phenols } \\
(\mathbf{m g} / \mathbf{k g})\end{array}$ & $\begin{array}{c}\text { Oxidative stability } \\
\text { at } \mathbf{1 0 0} \text { C }(\mathbf{h})\end{array}$ \\
\hline Arbequina (10) & $242 \pm 69^{\mathrm{a}}$ & $40.6 \pm 8.9^{\mathrm{a}}$ \\
Benizal (4) & $489 \pm 111^{\mathrm{abc}}$ & $49.7 \pm 10.0^{\mathrm{a}}$ \\
Castellana (12) & $391 \pm 34^{\mathrm{abc}}$ & $53.2 \pm 2.0^{\mathrm{a}}$ \\
Cornicabra (44) & $556 \pm 214^{\mathrm{bc}}$ & $108.4 \pm 37.2^{\mathrm{bc}}$ \\
Cuquillo (4) & $417 \pm 112^{\mathrm{abc}}$ & $64.3 \pm 10.5^{\mathrm{ab}}$ \\
Injerta (2) & $365 \pm 64^{\mathrm{abc}}$ & $50.5 \pm 4.8^{\mathrm{a}}$ \\
Manzanilla de Centro (5) & $384 \pm 106^{\mathrm{abc}}$ & $67.8 \pm 15.7^{\mathrm{ab}}$ \\
Manzanilla de Sevilla (2) & $301 \pm 66^{\mathrm{ab}}$ & $45.1 \pm 5.5^{\mathrm{a}}$ \\
Manzanilla Local (6) & $523 \pm 56^{\mathrm{bc}}$ & $78.4 \pm 5.2^{\mathrm{ab}}$ \\
Negrilla (2) & $391 \pm 61^{\mathrm{abc}}$ & $36.6 \pm 5.4^{\mathrm{a}}$ \\
Onil (2) & $400 \pm 86^{\mathrm{abc}}$ & $79.6 \pm 11.5^{\mathrm{ab}}$ \\
Picual (35) & $605 \pm 180^{\mathrm{c}}$ & $130.6 \pm 41.2^{\mathrm{c}}$ \\
\hline
\end{tabular}

n: number of samples; $a, b, c$ : Different superscripts for the same quality parameter mean significant differences among varieties.

very low (2 and 6 respectively, as shown in Table 1), and a higher number of samples could have been necessary to demonstrate the existence of significant differences. The lack of significant differences between the total phenols content of these varieties and Picual could also be due to this reason. The variety with the highest percentage of samples having bitterness values above 5 was Manzanilla Local (100\%), followed by Onil(75\%), Cornicabra (68.2\%) and Picual (64.3\%). The variety with the highest percentage of samples having pungency values above 5 was

\section{Benizal (87.5\%).}

The stability parameters, total phenols content and oxidative stability at $98^{\circ} \mathrm{C}$, were both useful for discriminating among varieties (Table 3). Picual had the highest phenols content, but only significantly different from Arbequina and Manzanilla de Sevilla. Picual, together with Cornicabra, showed the highest values of oxidative stability. Note that generally the lowest stability values were found for the varieties with the lowest phenols contents and that they coincided with the varieties showing the lowest bitter- 
Table 4 Mean and standard deviation for the fatty acids composition (\%) for the different olive varieties.

\begin{tabular}{|c|c|c|c|c|c|c|}
\hline Variety (n) & $\begin{array}{l}\text { Palmitic } \\
\text { C16:0 }\end{array}$ & $\begin{array}{c}\text { Palmitoleic } \\
\text { C16:1 }\end{array}$ & $\begin{array}{c}\text { Margaric } \\
\text { C17:0 }\end{array}$ & $\begin{array}{c}\text { Margaroleic } \\
\text { C17:1 }\end{array}$ & $\begin{array}{l}\text { Stearic } \\
\text { C18:0 }\end{array}$ & $\begin{array}{l}\text { Oleic } \\
\text { C18:1 }\end{array}$ \\
\hline Arbequina (10) & $14.40 \pm 0.98^{\mathrm{e}}$ & $1.70 \pm 0.37^{\mathrm{d}}$ & $<0.10^{\mathrm{a}}$ & $0.23 \pm 0.05^{\mathrm{b}}$ & $1.70 \pm 0.09^{\mathrm{a}}$ & $70.24 \pm 1.84^{\mathrm{a}}$ \\
\hline Benizal (4) & $12.14 \pm 0.59^{\mathrm{cd}}$ & $0.82 \pm 0.14^{\mathrm{abc}}$ & $0.11 \pm 0.03^{\mathrm{a}}$ & $0.12 \pm 0.06^{\mathrm{a}}$ & $2.00 \pm 0.32^{\mathrm{ab}}$ & $76.67 \pm 1.35^{\mathrm{bcd}}$ \\
\hline Castellana (12) & $12.85 \pm 0.25^{\mathrm{d}}$ & $1.00 \pm 0.00^{\mathrm{bc}}$ & $<0.10^{\mathrm{a}}$ & $<0.10^{\mathrm{a}}$ & $2.70 \pm 0.08^{\text {cdef }}$ & $76.35 \pm 0.66^{\mathrm{bc}}$ \\
\hline Cornicabra (44) & $10.06 \pm 0.91^{\mathrm{ab}}$ & $0.81 \pm 0.16^{\mathrm{abc}}$ & $<0.10^{\mathrm{a}}$ & $<0.10^{\mathrm{a}}$ & $3.11 \pm 0.38^{\mathrm{fg}}$ & $80.61 \pm 1.19^{\mathrm{e}}$ \\
\hline Cuquillo (4) & $11.36 \pm 0.67^{\mathrm{bc}}$ & $0.66 \pm 0.10^{\mathrm{ab}}$ & $<0.10^{\mathrm{a}}$ & $<0.10^{\mathrm{a}}$ & $3.34 \pm 0.25^{\mathrm{g}}$ & $76.33 \pm 1.51^{\mathrm{bc}}$ \\
\hline Injerta (2) & $10.94 \pm 0.64^{\mathrm{abc}}$ & $0.59 \pm 0.04^{\mathrm{a}}$ & $<0.10^{\mathrm{a}}$ & $<0.10^{\mathrm{a}}$ & $1.99 \pm 0.04^{\mathrm{ab}}$ & $78.81 \pm 0.70^{\text {de }}$ \\
\hline Manzanilla de Centro (5) & $12.08 \pm 0.59^{\mathrm{cd}}$ & $0.70 \pm 0.07^{\mathrm{ab}}$ & $<0.10^{\mathrm{a}}$ & $<0.10^{\mathrm{a}}$ & $2.23 \pm 0.17^{\mathrm{bc}}$ & $75.81 \pm 1.28^{\mathrm{bc}}$ \\
\hline Manzanilla de Sevilla (2) & $10.67 \pm 0.38^{\mathrm{ab}}$ & $0.68 \pm 0.07^{\mathrm{ab}}$ & $<0.10^{\mathrm{a}}$ & $<0.10^{\mathrm{a}}$ & $2.76 \pm 0.35^{\text {def }}$ & $76.64 \pm 1.07^{\mathrm{bcd}}$ \\
\hline Manzanilla Local (6) & $9.77 \pm 0.70^{\mathrm{a}}$ & $0.66 \pm 0.08^{\mathrm{a}}$ & $0.11 \pm 0.04^{\mathrm{a}}$ & $0.23 \pm 0.05^{\mathrm{b}}$ & $3.07 \pm 0.41^{\mathrm{efg}}$ & $77.43 \pm 0.68^{\mathrm{cd}}$ \\
\hline Negrilla (2) & $14.57 \pm 0.59^{\mathrm{e}}$ & $1.57 \pm 0.15^{\mathrm{d}}$ & $<0.10^{\mathrm{a}}$ & $<0.10^{\mathrm{a}}$ & $2.57 \pm 0.38^{\text {cde }}$ & $72.17 \pm 0.70^{\mathrm{a}}$ \\
\hline Onil (2) & $12.20 \pm 0.30^{\mathrm{cd}}$ & $1.07 \pm 0.15^{\mathrm{c}}$ & $0.17 \pm 0.06^{\mathrm{b}}$ & $0.33 \pm 0.06^{\mathrm{c}}$ & $2.47 \pm 0.15^{\mathrm{bcd}}$ & $74.70 \pm 0.85^{\mathrm{b}}$ \\
\hline \multirow[t]{2}{*}{ Picual (35) } & $10.68 \pm 0.85^{\mathrm{ab}}$ & $0.82 \pm 0.20^{\mathrm{abc}}$ & $<0.10^{\mathrm{a}}$ & $<0.10^{\mathrm{a}}$ & $2.93 \pm 0.31^{\text {defg }}$ & $80.77 \pm 1.31^{\mathrm{e}}$ \\
\hline & $\begin{array}{c}\text { Linoleic } \\
\text { C18:2 }\end{array}$ & $\begin{array}{c}\text { Linolenic } \\
\text { C18:3 }\end{array}$ & $\begin{array}{c}\text { Arachidic } \\
\text { C20:0 }\end{array}$ & $\begin{array}{c}\text { Gadoleic } \\
\text { C20:1 }\end{array}$ & $\begin{array}{c}\text { Behenic } \\
\text { C22:0 }\end{array}$ & $\begin{array}{c}\text { Lignoceric } \\
\text { C24:0 }\end{array}$ \\
\hline Arbequina (10) & $10.19 \pm 1.00^{\mathrm{e}}$ & $0.58 \pm 0.09^{\mathrm{ab}}$ & $0.40 \pm 0.00^{\mathrm{abc}}$ & $0.30 \pm 0.00^{\text {bcd }}$ & $<0.10$ & $<0.10$ \\
\hline Benizal (4) & $6.54 \pm 1.32^{\mathrm{bc}}$ & $0.82 \pm 0.11^{\mathrm{c}}$ & $0.38 \pm 0.06^{\mathrm{abc}}$ & $0.34 \pm 0.05^{\text {cde }}$ & $<0.10$ & $<0.10$ \\
\hline Castellana (12) & $5.42 \pm 0.39^{b}$ & $0.72 \pm 0.05^{\mathrm{bc}}$ & $0.40 \pm 0.00^{\mathrm{abc}}$ & $0.25 \pm 0.06^{\mathrm{ab}}$ & $<0.10$ & $<0.10$ \\
\hline Cornicabra (44) & $3.58 \pm 0.62^{\mathrm{a}}$ & $0.61 \pm 0.09^{\mathrm{ab}}$ & $0.49 \pm 0.04^{\mathrm{d}}$ & $0.30 \pm 0.02^{\mathrm{bcd}}$ & $0.12 \pm 0.04$ & $<0.10$ \\
\hline Cuquillo (4) & $6.58 \pm 0.97^{\mathrm{bc}}$ & $0.69 \pm 0.11^{\mathrm{bc}}$ & $0.46 \pm 0.05^{\mathrm{cd}}$ & $0.23 \pm 0.04^{\mathrm{ab}}$ & $<0.10$ & $<0.10$ \\
\hline Injerta (2) & $6.39 \pm 0.29^{\mathrm{bc}}$ & $0.80 \pm 0.10^{\mathrm{c}}$ & $0.37 \pm 0.05^{\mathrm{ab}}$ & $0.37 \pm 0.05^{\mathrm{e}}$ & $<0.10$ & $<0.10$ \\
\hline Manzanilla de Centro (5) & $7.62 \pm 0.97^{\mathrm{cd}}$ & $0.71 \pm 0.08^{\mathrm{bc}}$ & $0.35 \pm 0.05^{\mathrm{a}}$ & $0.29 \pm 0.03^{\mathrm{bc}}$ & $<0.10$ & $<0.10$ \\
\hline Manzanilla de Sevilla (2) & $7.67 \pm 0.97^{\text {cd }}$ & $0.82 \pm 0.08^{\mathrm{c}}$ & $0.46 \pm 0.05^{\mathrm{cd}}$ & $0.36 \pm 0.05^{\mathrm{de}}$ & $<0.10$ & $<0.10$ \\
\hline Manzanilla Local (6) & $7.27 \pm 0.72^{\text {cd }}$ & $0.79 \pm 0.04^{\mathrm{c}}$ & $0.43 \pm 0.08^{\mathrm{bcd}}$ & $0.29 \pm 0.04^{\mathrm{bc}}$ & $<0.10$ & $<0.10$ \\
\hline Negrilla (2) & $7.30 \pm 0.52^{\text {cd }}$ & $0.83 \pm 0.06^{\mathrm{c}}$ & $0.40 \pm 0.10^{\mathrm{abc}}$ & $0.30 \pm 0.00^{\mathrm{bcd}}$ & $<0.10$ & $<0.10$ \\
\hline Onil (2) & $8.07 \pm 0.06^{\mathrm{d}}$ & $0.53 \pm 0.06^{\mathrm{a}}$ & $0.40 \pm 0.00^{\mathrm{abc}}$ & $0.30 \pm 0.00^{\text {bcd }}$ & $0.13 \pm 0.06$ & $<0.10$ \\
\hline Picual (35) & $3.33 \pm 0.62^{\mathrm{a}}$ & $0.61 \pm 0.08^{\mathrm{ab}}$ & $0.38 \pm 0.04^{\mathrm{abc}}$ & $0.22 \pm 0.04^{\mathrm{a}}$ & $<0.10$ & $<0.10$ \\
\hline
\end{tabular}

n: number of samples; a, b, c, d, e, f, g: Different superscripts for the same quality parameter mean significant differences among varieties.

ness and pungency attributes (Table 2), as had been previously reported by other authors ${ }^{22,23)}$. These results agreed with those reported by other authors with the same varieties grown in other areas ${ }^{3,4,24-28)}$, and the values were within the usual range for virgin olive oil ${ }^{19)}$.

The distribution of fatty acid composition(Table 4) was within the limits stated by European Union Regulations ${ }^{18}$ : linolenic $\leq 1.0 \%$; arachidic $\leq 0.6 \%$; behenic $\leq 0.2 \%$; lignoceric $\leq 0.2 \%$; palmitic: $7.5-20.0 \%$; palmitoleic: $0.3-3.5 \%$; stearic: 0.5-5.0\%; oleic: 55.0-83.0\%; linoleic: 3.5-21.0\%, and covered the normal range expected for olive oil ${ }^{3,5-7,14,15,24,29,30)}$.

All of the evaluated fatty acids, with the exception of behenic and lignoceric acids, were useful and significant parameters to differentiate between the varieties.

Arbequina showed the highest contents in palmitic, palmitoleic and linoleic acids, and the lowest contents in stearic (although not significantly different from Benizal and Injerta) and oleic acids. The low oleic and high linoleic acid content shown by Arbequina lead to a low mono/ polyunsaturated ratio for this variety, which could contribute to its low oxidative stability (Table 3 ), as has been previously suggested ${ }^{23)}$. Our study also concur with previous works ${ }^{24)}$, claiming that the ratio of saturated fatty acids of Arbequina was higher when the variety was grown further South, increasing its linoleic and decreasing its oleic acid content. Fatty acid composition of Negrilla was very similar to that of Arbequina, and they differed only in stearic, linoleic and linolenic content.

Fatty acid compositions of Cornicabra and Picual were also quite similar to each other and they both had the highest oleic content (although not significantly different from Injerta) and the lowest linoleic content. According to Alba et al. ${ }^{29)}$, Cornicabra and Picual are the Spanish varieties with the lowest linoleic acid levels, which agree with our results. Cornicabra had also the highest arachidic content(although not significantly different from Cuquillo, 


\section{A. Alvarruiz, M. Á.-Ortí and Braulia Mateos et al.}

Table 5 Mean and standard deviation for the sterol and triterpenic dialcohols (erythrodiol + uvaol) composition (\%) for the different olive varieties.

\begin{tabular}{|c|c|c|c|c|c|c|c|}
\hline Variety (n) & Cholesterol & Campesterol & Stigmasterol & $\begin{array}{c}\text { Apparent } \\
\beta \text {-Sitosterol }\end{array}$ & $\Delta 7$-Stigmastenol & $\begin{array}{c}\text { Total sterols (mg/ } \\
\mathrm{kg})\end{array}$ & $\begin{array}{l}\text { Erythrodiol + } \\
\text { Uvaol }\end{array}$ \\
\hline Arbequina (10) & .03 & $3.28 \pm 0.27^{\mathrm{de}}$ & $0.70 \pm 0.10^{\mathrm{bcd}}$ & $94.61 \pm 0.37^{\mathrm{abc}}$ & $0.24 \pm 0.05^{\mathrm{ab}}$ & $1491.8 \pm 171.3^{\text {ef }}$ & $1.29 \pm 0.33^{\mathrm{a}}$ \\
\hline Benizal (4) & $0.18 \pm 0.08$ & $4.25 \pm 0.25^{\mathrm{g}}$ & $0.78 \pm 0.19^{\mathrm{d}}$ & $93.79 \pm 0.31^{\mathrm{a}}$ & $0.30 \pm 0.06^{\mathrm{ab}}$ & $848.8 \pm 49.5^{\mathrm{a}}$ & $3.24 \pm 0.36^{\text {cd }}$ \\
\hline Castellana (12) & $0.10 \pm 0.00$ & $2.95 \pm 0.06^{\mathrm{abcd}}$ & $0.63 \pm 0.05^{\mathrm{abcd}}$ & $95.63 \pm 0.05^{\mathrm{c}}$ & $0.20 \pm 0.00^{\mathrm{a}}$ & $1022.8 \pm 80.6^{\mathrm{ab}}$ & $2.30 \pm 0.08^{\mathrm{bc}}$ \\
\hline Cornicabra (44) & $0.14 \pm 0.06$ & $3.84 \pm 0.20^{\mathrm{f}}$ & $0.48 \pm 0.14^{\mathrm{ab}}$ & $94.59 \pm 1.58^{\mathrm{abc}}$ & $0.23 \pm 0.08^{\mathrm{ab}}$ & $1468.6 \pm 188.6^{\mathrm{ef}}$ & $3.34 \pm 0.88^{\mathrm{d}}$ \\
\hline Cuquillo (4) & $0.13 \pm 0.05$ & $3.13 \pm 0.19^{\text {bcde }}$ & $0.74 \pm 0.28^{\text {cd }}$ & $95.17 \pm 0.32^{\mathrm{abc}}$ & $0.28 \pm 0.04^{\mathrm{ab}}$ & $1446.4 \pm 114.5^{\mathrm{ef}}$ & $1.94 \pm 0.56^{\mathrm{ab}}$ \\
\hline Injerta (2) & $0.14 \pm 0.05$ & $2.74 \pm 0.08^{\mathrm{a}}$ & $0.67 \pm 0.08^{\text {abcd }}$ & $95.40 \pm 0.22^{\mathrm{bc}}$ & $0.34 \pm 0.08^{b}$ & $1335.9 \pm 81.2^{\mathrm{de}}$ & $1.94 \pm 0.14^{\mathrm{ab}}$ \\
\hline Manzanilla & .09 & $3.24 \pm 0.16^{\text {cde }}$ & $0.63 \pm 0.17^{\text {abcd }}$ & $94.81 \pm 0.29^{\mathrm{abc}}$ & $0.23 \pm 0.11^{\mathrm{ab}}$ & $1088.8 \pm 102.9^{\mathrm{bc}}$ & $1.99 \pm 0.55^{\mathrm{ab}}$ \\
\hline Manzanilla de Sevilla (2) & $0.11 \pm 0.03$ & $3.10 \pm 0.16^{\text {bcde }}$ & $0.42 \pm 0.07^{\mathrm{a}}$ & $95.22 \pm 0.20^{\mathrm{bc}}$ & $0.23 \pm 0.07^{\mathrm{ab}}$ & $1660.1 \pm 121.7^{\mathrm{f}}$ & $2.34 \pm 0.55^{\mathrm{bcd}}$ \\
\hline Manzanilla Local (6) & $0.14 \pm 0.05$ & $2.91 \pm 0.20^{\mathrm{abc}}$ & $0.54 \pm 0.11^{\mathrm{abcd}}$ & $95.26 \pm 0.45^{\mathrm{bc}}$ & $0.20 \pm 0.08^{\mathrm{a}}$ & $1321.9 \pm 65.2^{\text {cde }}$ & $2.04 \pm 0.48^{\mathrm{ab}}$ \\
\hline Negrilla (2) & $0.13 \pm 0.06$ & $2.87 \pm 0.12^{\mathrm{ab}}$ & $0.60 \pm 0.10^{\mathrm{abcd}}$ & $95.30 \pm 0.36^{\mathrm{bc}}$ & $0.23 \pm 0.06^{\mathrm{ab}}$ & $1352.3 \pm 53.7^{\mathrm{e}}$ & $1.67 \pm 0.45^{\mathrm{ab}}$ \\
\hline Onil (2) & $0.20 \pm 0.00$ & $3.90 \pm 0.17^{\mathrm{f}}$ & $0.53 \pm 0.06^{\mathrm{abcd}}$ & $94.13 \pm 0.15^{\mathrm{ab}}$ & $0.20 \pm 0.00^{\mathrm{a}}$ & $1394.7 \pm 108.6^{\mathrm{e}}$ & $2.23 \pm 0.06^{\mathrm{ab}}$ \\
\hline Picual (35) & $0.19 \pm 0.07$ & $3.34 \pm 0.17^{\mathrm{e}}$ & $0.50 \pm 0.13^{\mathrm{abc}}$ & $94.99 \pm 0.30^{\mathrm{abc}}$ & $0.31 \pm 0.07^{\mathrm{ab}}$ & $1105.0 \pm 128.6^{\mathrm{bcd}}$ & $1.49 \pm 0.46^{\mathrm{ab}}$ \\
\hline
\end{tabular}

$\mathrm{n}$ : number of samples; $\mathrm{a}, \mathrm{b}, \mathrm{c}, \mathrm{d}, \mathrm{e}, \mathrm{f}$ : Different superscripts for the same quality parameter mean significant differences among varieties.

Manzanilla de Sevilla and Manzanilla Local), while Picual had the lowest gadoleic content(although not significantly different from Castellana and Cuquillo).

Injerta had the lowest palmitoleic content and the highest gadoleic content. Onil had the highest margaric and margaroleic content and the lowest linolenic content (although not significantly different from Arbequina, Cornicabra and Picual). The varieties Benizal, Castellana, Cuquillo Manzanilla de Centro and Manzanilla de Sevilla do not stand out in any fatty acid composition.

Sterol and triterpenic dialcohol composition is shown in Table 5. Content values were found within the ranges required by Regulation EU 1348/2013 ${ }^{18)}$ (cholesterol $\leq 0.5 \%$, campesterol $\leq 4.0 \%$, stigmasterol $<$ campesterol, apparent $\beta$-sitosterol $\geq 93.0 \%, \Delta 7$-stigmastenol $\leq 0.5 \%$ total sterols $\geq 1000 \mathrm{mg} / \mathrm{kg}$, erythrodiol + uvaol $\leq 4.5 \%$ ), except for some samples of virgin olive oil belonging the variety Cornicabra as regards campesterol, and other samples belonging to the variety Benizal, as regards campesterol and total sterols.

There were not significant differences in the cholesterol content for the different varieties, and all the values found for this sterol were very low.

Benizal had the highest campesterol content, even higher than the variety Cornicabra, and both of them showed values above $4 \%$, but lower than $4.5 \%$ (except for one sample of Benizal, with 4.7\%). According to Regulation EU 1348/2013 ${ }^{18)}$, when the campesterol content was between 4.0 and $4.5 \%$, the stigmasterol and $\Delta 7$-stigmastenol contents should be lower than $1.4 \%$ and $0.3 \%$, respectively, as in fact happens with all our samples. The variety Onil also showed high campesterol values, close to $4 \%$. The high campesterol content found in these samples must be an intrinsic feature of the varieties, since the olives were picked and processed in highly controlled conditions.
These high campesterol values have been already reported for Cornicabra in the provinces of Toledo and Albacete ${ }^{3,5,7)}$, for Onil in the province of Albacete ${ }^{7)}$ and for Arbequina in certain warm Argentine regions, like La Rioja and Catamar$\mathrm{ca}^{31,32)}$. The variety Injerta showed the lowest campesterol values, although not significantly different from Castellana, Manzanilla Local and Negrilla.

The lowest stigmasterol content was found for Manzanilla de Sevilla, although only significantly different from Arbequina, Benizal and Cuquillo, which showed the highest values.

Apparent $\beta$-sitosterol accounted for more than $93 \%$ of the total sterols. The variety Castellana stood out, although only significantly different from Benizal and Onil.

The variety Injerta showed the highest $\Delta 7$-stigmastenol values, although only significantly different from Castellana, Manzanilla Local and Onil.

Benizal was the only variety which did not arrive to the minimum $1,000 \mathrm{mg} / \mathrm{kg}$ established by Regulation EU $1348 / 2013^{18)}$ for total sterol content. This must also be an intrinsic feature of this variety, as explained above for campesterol. At the other end there were Arbequina, Cornicabra, Cuquillo and Manzanilla de Sevilla with some samples having more than $1,700 \mathrm{mg} / \mathrm{kg}$.

The variety Cornicabra stood out in the triterpenic dialcohols (erythrodiol + uvaol), although not significantly different from Benizal and Manzanilla de Sevilla.

The most useful parameters from Table 5 to discriminate among varieties were campesterol, stigmasterol, apparent $\beta$-sitosterol, total sterol and erythrodiol + uvaol, but some varieties (Manzanilla de Centro, Manzanilla Local, $\mathrm{Ne}$ grilla, Onil and Picual) did not stand out in any of these parameters. 


\section{Conclusions}

The two more common varieties in Castilla-La Mancha (Cornicabra and Picual), gave remarkably bitter oils, with high total phenolic content and high oxidative stability, while the variety Arbequina, recently introduced in the region with great success, gave oils with low bitterness, low phenolic content and low stability. The other less common varieties had intermediate characteristics between those of these two groups. Fatty acid composition of Cornicabra and Picual characterised by high oleic and low linoleic acids content, while Arbequina showed the opposite, with low mono/polyunsaturated ratio. On the other hand, one sample of Benizal had campesterol contents above the established limits, and the total sterols content of Benizal was below the minimum level for virgin olive oil.

\section{ACKNOWLEDGEMENTS}

The authors express their sincere gratitude to the Consejería de Educación y Ciencia de la Junta de Comunidades de Castilla-La Mancha for supporting this research Project (PII2I09-0035-4931). We also thank technicians Amadeo Zon and Ana Maria Garví for their collaboration in the oil extraction. The authors have declared no conflict of interest.

\section{References}

1) LIFE Buenas prácticas para mejorar el comportamiento medioambiental del sector oleícola. European Union Official Publication Office. Brussels (2010).

2) Salvador, M. D.; Aranda, F.; Fregapane, G. Chemical composition of commercial Cornicabra virgin olive oil from 1995/96 and 1996/97 crops. J. Am. Oil Chem. Soc. 75, 1305-1311 (1998).

3) Salvador, M. D.; Aranda, F.; Gómez-Alonso, S.; Fregapane, G. Cornicabra virgin olive oil: a study of five crop seasons. Composition, quality and oxidative stability. Food Chem. 74, 267-274(2001).

4) Alvarruiz, A.; Fernández, E.; Montero, F.; Granell, J.; Pardo, J. E. Analytical evaluation of 'Cornicabra' virgin olive oil from Castilla-La Mancha (Spain). Food Agric. Environ. 1, 48-52(2003).

5) Salvador, M. D.; Aranda, F.; Gómez-Alonso, S.; Fregapane, G. Influence of extraction system, production year and area on Cornicabra virgin olive oil: a study of five crop seasons. Food Chem. 80, 359-366 (2003).

6) Pardo, J. E.; Cuesta, M. A.; Alvarruiz, A. Evaluation of potential and real quality of virgin olive oil from the designation of origin “Aceite Campo de Montiel” (Ciudad Real, Spain). Food Chem. 100, 977-984(2007).

7) Pardo, J. E.; Cuesta, M. A.; Alvarruiz, A.; Granell, J. D.;
Alvarez-Orti, M. Evaluation of potential and real qualities of virgin olive oil from the designation of origin (DO) “Aceite Montes de Alcaraz” (Albacete, Spain). Food Chem. 124, 1684-1690 (2011).

8) Pardo, J. E.; Sena, E.; Cuesta, M. A.; Granell, J. E.; Valiente, J.; Alvarez-Ortí, M. Evaluation of Potential and Real Quality of Virgin Olive Oilfrom "Campos de Hellín” (Albacete, Spain). J. Am. Oil Chem. Soc. 90, 851-862 (2013).

9) Viola, P. El aceite de oliva y la salud. Consejo Oleícola Internacional, Madrid (1997).

10) Williamson, E. Ph. D. Thesis. University of Reading, UK (1988).

11) Aparicio, R.; Ferreiro, L.; Cert, A.; Lazón, A. Caracterización de aceites de oliva vírgenes andaluces. Grasas Aceites 41, 23-39 (1990).

12) Alonso, M. V.; Aparicio, R. Characterization of European virgin olive oil using fatty acids. Grasas Aceites 44, 18-24 (1993).

13) Lanza, C. M.; Russo, C.; Tomaselli, F. Relationship between geographical origin and fatty acid composition of extra-virgin olive oils produced in three areas of Eastern Sicily. Ital. J. Food Sci. 4, 359-366(1998).

14) Motilva, M. J.; Ramo, T.; Romero, M. P. Caracterización geográfica de los aceites de oliva vírgenes de la denominación de origen protegida "Les Garrigues" por su perfil de ácidos grasos. Grasas Aceites 52, 26-32 (2001).

15) Ranalli, A.; De Mattia, G.; Ferrante, M. L.; Giansante, L. Incidence of olive cultivation area on the analytical characteristics of the oil. Note 1. Riv. Ital. Sostanze Gr. 74: 501-508(1997).

16) Jiménez, O.; del Valle, A. Determination of sterols by capillary column gas chromatography. Differentiation among different types of olive oil: virgin, refined and solvent-extracted. J. Am. Oil Chem. Soc. 73, 16851689 (1996).

17) Aranda, F. Ph. D. Thesis. University of Castilla-La Mancha, Spain (2003).

18) European Union Commission. Commission regulation amending Regulation (EEC) No 2568/91 on the characteristics of olive oil and olive-residue oil and on the relevant methods of analysis. Off. Regulation EU No1348/2013. Off. J. Eur. Comm. L338, 31-67(2013).

19) Gutfinger, T. Polyphenols in olive virgin oils. J. Am. Oil Chem. Soc. 58, 966-968(1981).

20) Gutiérrez, F. Determinación de la estabilidad oxidativa de aceites de oliva vírgenes: comparación entre el método A. O. M. y el método Rancimat. Grasas Aceites 40, 1-5(1989).

21) Cert, A.; Moreda, W.; García-Moreno, J. Determinación de esteroles y alcoholes triterpénicos en aceite de oliva mediante separación de la fracción por cromatografía líquida de alta eficacia y análisis por cromato- 
grafía de gases. Estandarización del método analítico. Grasas Aceites 48, 207-218(1997).

22) Gutiérrez, F.; Perdiguero, S.; Gutiérrez, R.; Olías, J. M. Evaluation of the bitter taste in virgin olive oil. J. Am. Oil Chem. Soc. 69, 394-395(1992).

23) Beltrán, G.; Jiménez, A.; Aguilera, M. P.; Uceda, M. Análisis mediante HPLC de la fracción fenólica del aceite de oliva virgen de la variedad Arbequina. Relación con la medida del amargor $\mathrm{K}_{225} \mathrm{y}$ la estabilidad. Grasas Aceites 51, 320-324 (2000).

24) Tous, J.; Romero, A.; Plana, J.; Guerrero, L.; Díaz, I.; Hermoso, J. F. Características químico-sensoriales de los aceites de oliva Arbequina obtenidos en distintas zonas de España. Grasas Aceites 48, 415-424 (1997).

25) Motilva, M. J.; Jaria, I.; Bellart, I.; Romero, M. P. Estudio de la calidad del aceite de oliva virgen de la Denominación de Origen "Les Garrigues" (Lleida)durante la campaña 1995/96. Grasas Aceites 49, 425-433 (1998).

26) Beltrán, G.; Jiménez, A.; Aguilera, M. P.; Uceda, M. Análisis mediante HPLC de la fracción fenólica del aceite de oliva virgen de la variedad Arbequina. Relación con la medida del amargor $\mathrm{K}_{225}$ y la estabilidad. Grasas Aceites 51, 320-324(2000).

27) Benito, M.; Oria, R.; Sánchez-Gimeno, A. C. Character- ization of the Olive Oil from Three Potentially Interesting Varieties from Aragon(Spain). Food Sci. Tech. Int. 16, 523-528 (2010).

28) León, L.; Beltrán, G.; Aguilera, M. P.; Rallo, L.; Barranco, D.; De la Rosa, R. Oil composition of advanced selections from an olive breeding program. Eur. J. Lipid Sci. Technol. 113, 870-875(2011).

29) Alba, J.; Hidalgo, F.; Ruiz, A.; Martínez, F.; Moyano, M. J.; Cert, A.; Pérez, M. C.; Ruiz, M. V. Características de los aceites de oliva de primera y segunda centrifugación. Grasas Aceites 47, 163-181 (1996).

30) Sánchez, J. J.; Osorio, E.; Montaño, A. M.; Martínez, M. Estudio del contenido en ácidos grasos de aceites monovarietales elaborados a partir de aceitunas producidas en la región extremeña. Grasas Aceites 54, 371-377 (2003).

31) Ceci, L. N.; Melgarejo, M.; Carelli, A. A. Caracterización de aceites de oliva varietales argentinos cosecha 2005. Parte II: Polifenoles, ceras, esteroles y eritrodiol-uvaol. Grasas Aceites 62, 566-573(2006).

32) Pardo, J. E.; Alvarez-Ortí, M.; Rey, A. M.; Cuesta, M. A.; Silvestre, A. Purity, quality and stability of Argentinean virgin olive oils. Eur. J. Lipid Sci. Technol. 113, 597-608(2011). 